\begin{tabular}{|c|c|c|c|} 
Dinamika Journal, Vol. 2 No. 1, 2020 \\
ISSN ONLINE : 2686-2158 \\
Journal Homepage : http://jurnal.lppm.unsoed.ac.id/ojs/index.php/dinamika
\end{tabular}

\title{
PENINGKATAN PENGGUNAAN ANTIBIOTIK BIJAK MELALUI DETEKSI DINI MRSA PADA POSDAYA SUNAN KALIJAGA, BERKOH, PURWOKERTO
}

\author{
Dwi Utami Anjarwati ${ }^{1, *}$ Rahmawati Wulan Sari², Rani Afifah Nur Hestiyani ${ }^{1}$ \\ ${ }^{1}$ Departemen Mikrobiologi, Fakultas Kedokteran, Universitas Jenderal Soedirman, \\ Jl.Gumbreg No 1, Mersi, Purwokerto, Indonesia \\ ${ }^{2}$ Departemen Ilmu Kesehatan Masyarakat, Fakultas Kedokteran, Universitas Jenderal \\ Soedirman, Jl.Gumbreg No 1, Mersi, Purwokerto, Indonesia \\ ${ }^{*}$ Corresponding author : dwi.anjarwati@unsoed.ac.id
}

Received 21 January 2019; Accepted 26 February 2019; Available online 28 February 2020

\begin{abstract}
Abstrak
Penggunaan antibiotik yang tidak bijak dapat menyebabkan peningkatan kejadian resistensi antibiotik di masyarakat. Pengabdian masyarakat ini bertujuan untuk melakukan deteksi dini (skrining) MRSA sebagai salah satu upaya untuk meningkatkan pengetahuan dan membangun kesadaran masyarakat dalam penggunaan antibiotik secara bijak. Metode yang digunakan dalam pengabdian masyarakat ini berupa identifikasi MRSA dari hapusan hidung dan tenggorok anggota posdaya Sunan Kalijaga, Berkoh, Purwokerto. Test kepekaan antibiotik yang dilakukan adalah dengan menggunakan metode difusi cakram, Kirby Bauer. Riwayat penggunaan antibiotik pada masyarakat diketahui dengan menggunakan kuesioner. Hasil kegiatan ini menunjukkan bahwa bakteri S.aureus yang ditemukan dalam masyarakat masih bersifat sensitif terhadap sefoxitin. Proporsi Stapylococcus aureus yang diperoleh sebanyak 9,33\% dari hapusan hidung dan 34,66\% dari hapusan tenggorok. Namun penggunaan antibiotik yang tidak bijak masih ditemukan pada anggota posdaya sebanyak 17.33\%. Hasil kegiatan diinformasikan kepada masyarakat sebagai bahan acuan untuk memperbaiki perilaku penggunaan antibiotik secara bijak.
\end{abstract}

Kata Kunci : Resistensi antibiotik, Staphylococuss aureus, MSSA, MRSA.

Abstract

The use of antibiotics that are not wise can cause an increase in the incidence of antibiotic resistance in the community. This community service aims to conduct early detection (screening) MRSA as an effort to increase knowledge and increase public awareness in the wise use of antibiotics. The method used in community service was the identification of MRSA from the smeared nose and throat of the members of Posdaya Sunan Kalijaga, $R W 2$, Berkoh, Purwokerto. Antibiotic susceptibility test performed by using the disc diffusion method, Kirby Bauer. History of antibiotic use in the community is obtained by using a questionnaire. The results of this activity show that S.aureus bacteria found in the

48 Dinamika Journal Vol. 2 No. 1, Februari 2020 : 48-53 
community are still sensitive to cefoxitin, Staphylococcus aureus proportion was $9.33 \%$ of nasal smear and $34.66 \%$ of throat smear. However, the use of antibiotics that is not wise is still found in the community as much as $17.33 \%$. The results of the activity were informed to the public as a reference material to improve antibiotic use wisely.

Keywords : Antibiotic Resistance, Staphylococuss aureus, MSSA, MRSA

\section{PENDAHULUAN}

Jim O’Neil melaporkan bahwa jika resistensi antibiotik tidak dikendalikan dengan baik maka akan menjadi penyebab utama kematian pada tahun 2050. Prediksi angka kematian pada tahun tersebut dapat mencapai 10 juta/tahun, di atas kanker, diabetes dan penyakit lainnya (O’Neil 2014). Penyakit infeksi bahkan yang ringan sekalipun dapat berkembang menjadi kronis dan persisten karena bakteri yang resisten sulit diobati. Multidrug-resistant organisms (MDRO's) yang berkembang karena penggunaan antibiotik tidak terkendali antara lain Methicilin resistant Staphylococcus aureus (MRSA), Extended spectrum betalactamase (ESBL), Vancomycin resistant Staphylococcus aureus (VRSA) dan lain-lain (WHO,2014).

Kejadian resistensi antibiotik tidak hanya ditemukan pada pasien yang di rawat di rumah sakit, tetapi ditemukan pula di masyarakat. Santosaningsih D. et al., melaporkan dalam penelitiannya bahwa S.aureus di masyarakat di Malang lebih resisten dibandingkan di rumah sakit. Hal ini disebabkan karena adanya perbedaan kadar hambat minimum antibiotik terhadap isolat yang diuji (Santosaningsih D. et al., 2011).

Anjarwati et al., melaporkan bahwa di Banyumas ditemukan karier MRSA pada petugas kesehatan di rumah sakit swasta sebanyak 14\% sementara di rumah sakit pemerintah sebesar 25\% (Anjarwati et al., 2011). Penelitian tim Fakultas kedokteran Unsoed menemukan karier Escherichia coli penghasil ESBL pada mahasiswa angkatan 2014 sebanyak 26,8\% dan berhubungan dengan penggunaan antibiotik yang tidak bijak (Ulla I.M., et al., 2018). Data ini menunjukkan bahwa karier MRSA dan ESBL ditemukan di masyarakat Kabupaten Banyumas dan sekitarnya. Seseorang dengan status karier, berpotensi sebagai sumber penularan bakteri resisten.

Penggunaan antibiotik yang tidak rasional dan bijak di masyarakat Surabaya dilaporkan oleh Usman Hadi et al. Informasi yang didapatkan dalam penelitian tersebut antara lain $17 \%$ pembelian antibiotik tanpa resep dokter (Hadi U. et al., 2008). Hal senada dilaporkan pula dalam penelitian riskesdas pada tahun 2013, yaitu sebanyak 86,1\% pembelian antibiotik di masyarakat tanpa resep dokter.

Tekanan selektif menjadi salah satu pemicu resistensi antibiotik, dimana bakteri sensitif terbunuh, tetapi bakteri resisten akan berkembang jika antibiotik digunakan secara tidak bijak. Oleh karena itu langkah pertama yang harus dilakukan adalah meningkatkan penggunaan antibiotik secara bijak. Langkah kedua adalah mencegah penyebaran mikroba yang resisten. Upaya peningkatan penggunaan antibiotik dapat dilakukan dengan deteksi dini karier MDRO's (Permenkes, 2015).

Mitra dalam pengabdian masyarakat ini adalah kelompok pemberdayaan wanita Posdaya Sunan Kalijaga RW 2, Berkoh. Kegiatan kelompok pemberdayaan berjalan rutin, aktif dan bervariasi. Salah satu kegiatan yang pernah dilakukan dan mendapat respon sangat positif adalah berupa intervensi Knowledge,attitude, Practice (KAP) untuk meningkatkan kesadaran penggunaan antibiotik secara bijak. Sebelum kegiatan intervensi

D. U. Anjarwati et al. 2020. Peningkatan Penggunaan Antibiotik Bijak Melalui 49 
KAP, anggota posdaya belum menyadari pentingnya penggunaan antibiotik bijak. Setelah kegiatan intervensi KAP, didapatkan data tentang peningkatan kesadaran penggunaan antibiotik secara bijak. Survey pendahuluan yang dilakukan oleh tim FK Unsoed pada tahun 2018 ini memberikan informasi bahwa 90\% anggota kelompok posyandu memiliki riwayat penggunaan amoxicillin. Antibiotik tersebut didapat dengan berbagai cara dan belum semua anggota menggunakan resep dokter. Sementara deteksi dini untuk skrining MDRO's belum pernah dilakukan dalam kelompok pemberdayaan ini. Kegiatan deteksi dini sebagai skrining MRSA ditujukan sebagai salah satu upaya meningkatkan pengetahuan dan membangun kesadaran masyarakat dalam penggunaan antibiotik secara bijak.

\section{METODE PELAKSANAAN}

1. Alat dan Bahan

1. LCD

2. Banner

3. Alat Tulis

4. Form Kesediaan

5. Alat dan Bahan Deteksi Dini:

Hapusan hidung dan tenggorok, cotton swab steril, Blood agar plate, Kit uji staphaurex (untuk uji koagulasi), Pewarnaan Gram, Uji Katalase, MulleHA, Cakram Cefoxitin $30 \mathrm{mg}$, tabung steril pembawa specimen, Cryo tube, Ose disposable, Alkohol 70\%, Spiritus, Bunsen, Label.

2. Masyarakat sebagai khalayak sasaran adalah Anggota posdaya Sunan Kalijaga RW 2, Berkoh. Khalayak sasaran dikumpulkan dengan cara diundang untuk mengadiri acara pengabdian masyarakat pada waktu yang telah disepakati. Kegiatan di laksanakan di Halaman Masjid Fastabiqul Khoirot, Jalan Sunan Kalijaga, RW 2, Berkoh, pada Hari Jumat, Rangkaian acara pengabdian masyarakat terdiri dari: 1. Registrasi peserta, 2. Pembukaan oleh bapak ketua RW, 3. penjelasan tentang materi dan teknis pelaksanaan kegiatan oleh ketua pengabdian Masyarakat, 4. Pengisian lembar persetujuan untuk mengikuti deteksi dini MDROs, 5. Pengambilan hapusan hidung dan Tenggorok sebagai bahan untuk deteksi dini MRSA. 6. Makan Siang dan Pemberian souvenir.

3. Peningkatan kesadaran akan perlunya penggunaan antibiotik bijak dengan deteksi dini sebagai skrining karier Multidrug Resisten Organisms (MDROs) dalam hal ini deteksi Methicillin Resistant Staphylococcus aureus (MRSA) pada anggota posdaya. Gambaran kegiatan sebagai berikut : anggota posdaya yang bersedia untuk mengikuti kegiatan deteksi dini diambil hapusan hidung dan hapusan tenggoroknya. Spesimen yang diperoleh akan diperiksa di laboratorium mikrobiologi berupa kultur Staphylococcus aureus dari hapusan hidung, hapusan tenggorok pada media yang sesuai. Isolat yang tumbuh akan diidentifikasi zona hemolisisnya pada media blood agar, pengecatan Gram dan uji koagulase dengan Staphaurex. Selanjutnya dilakukan uji resistensi antibiotik dengan metode Antibiotic susceptibility testing (AST) sesuai pedoman Clinical and Laboratory Standards Institute (CLSI) $28^{\text {th }}$ Edition untuk menentukan kriteria MRSA atau MSSA. 


\section{HASIL DAN PEMBAHASAN}

Deteksi dini MRSA dalam pengabdian masyarakt ini merupakan salah satu upaya untuk meningkatkan pengetahuan dan membangun kesadaran masyarakat dalam penggunaan antibiotik secara bijak. Khalayak sasaran yang diundang adalah ibu-ibu anggota Posdaya Sunan Kalijaga, RW 2, Berkoh, Purwokerto sebanyak 75 orang. Namun dalam pelaksanaannya dari 75 undangan, yang hadir dan bersedia berpartisipasi adalah 72 orang ibu. Tiga orang lainnya adalah warga laki-lagi RW setempat. Sehingga total partisipan adalah 75 orang. Kelompok Pemberdayaan ini memiliki anggota kurang lebih 100 orang yang didominasi oleh rerata usia 25-40 tahun, dengan kisaran usia cukup panjang yaitu 18-88 tahun. Tingkat pendidikan terakhir anggota kelompok terbanyak adalah SLTA, sementara anggota yang lain memiliki pendidikan terakhir SD, SLTP serta S1. Jenis pekerjaan anggota terbanyak adalah ibu rumah tangga, sementara beberapa anggota yang lain merupakan karyawan swasta dan PNS.

Hasil skrining yang dilakukan dalam pengabdian masyarakat ini menunjukkan informasi dari 75 peserta yang hadir, ditemukan 26 orang $(34,67 \%)$ memiliki kolonisasi bakteri S. aureus dari hapusan tenggorok dan 7 koloni S.aureus dari hapusan hidung. Semua bakteri yang ditemukan masih bersifat sensitif terhadap antibiotik standar yang diuji (cefoxitin). Bakteri ini merupakan flora normal yang secara alami berada pada 30$40 \%$ populasi. Namun demikian, skrining perlu dilanjutkan untuk bakteri lain, terutama untuk penyebab infeksi-infeksi yang bersifat endemis di daerah Banyumas, seperti Salmonela thypi dan Escherichia coli. Hal ini beralasan karena selama proses skrining ditemukan pula perilaku penggunaan antibiotik yang tidak bijak pada 13 peserta. Sementara pada pengabdian masyarakat tahun sebelumnya terhadap khalayak sasaran yang sama, 90\% peserta menyampaikan riwayat penggunaan amoksisilin dalam 3 tahun terakhir.

Tabel 1. Hasil Skrining MRSA

\begin{tabular}{ccc}
\hline Riwayat Penggunaan Antibiotik & \multicolumn{2}{c}{ Sensitivitas S. aureus * } \\
\cline { 2 - 3 } Tidak Bijak (\%) & Hidung (\%) & Tenggorok (\%) \\
\hline $17,33(13 / 75)$ & $9,33(7 / 75)$ & $34,66(26 / 75)$
\end{tabular}

Keterangan: *jumlah S.aureus yang sensitive terhadap cefoxitin $30 \mathrm{mg}$

Penggunaan antibiotik yang tidak bijak dapat menyebabkan berkembangnya bakteri yang resisten terhadap antibiotik di dalam tubuh seseorang. Bakteri yang resisten tidak dapat dibunuh oleh antibiotik, bahkan dapat berkembang biak yang disebut sebagai fenomena tekanan selektif. Selain berkembang biak, bakteri resisten dapat pula ditularkan kepada orang lain yang semula tidak memiliki bakteri tersebut. Sementara sifat resistensi dapat pula ditularkan oleh bakteri yang resisten terhadap bakteri yang masih sensitif terhadap antibiotik melalui perpindahan plasmid (Permenkes, 2015). Pemahaman masyarakat akan mekanisme perkembangbiakan bakteri resisten sampai dengan penularannya terhadap bakteri dan orang lain sangat penting untuk dibangun.

Karakter kelompok Posdaya yang aktif dan respon positif terhadap informasi yang bermanfaat, sangat berperan strategis sebagai agen atau kader masyarakat dalam upaya peningkatan penggunaan antibiotik bijak melalui jalur edukasi. Program pengendalian resistensi antibiotik di Indonesia telah disusun sebagai upaya komprehensif dari Pemerintah yang melibatkan semua unsur yaitu pemerintah sebagai regulator, tenaga kesehatan, farmasi, masyarakat, peternak/petani, serta dunia pendidikan (Permenkes, 2015).

D. U. Anjarwati et al. 2020. Peningkatan Penggunaan Antibiotik Bijak Melalui 
Harmonisasi pengendalian resistensi antibiotik yang melibatkan semua unsur baik berbasis fasilitas pelayanan kesehatan maupun masyarakat diharapkan dapat berkontribusi dalam memutus rantai masalah resistensi antibiotik.

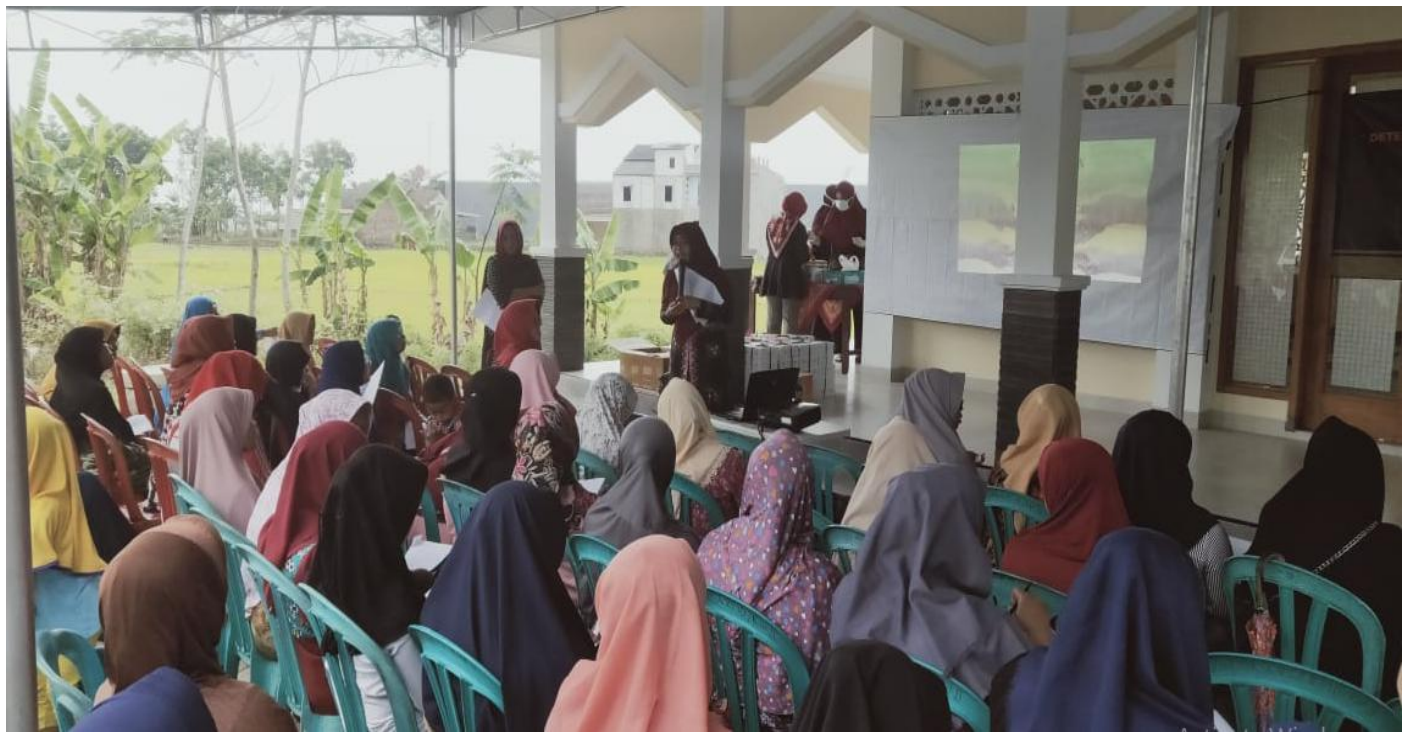

Gambar 1. Penjelasan materi dan teknis pelaksanaan kegiatan

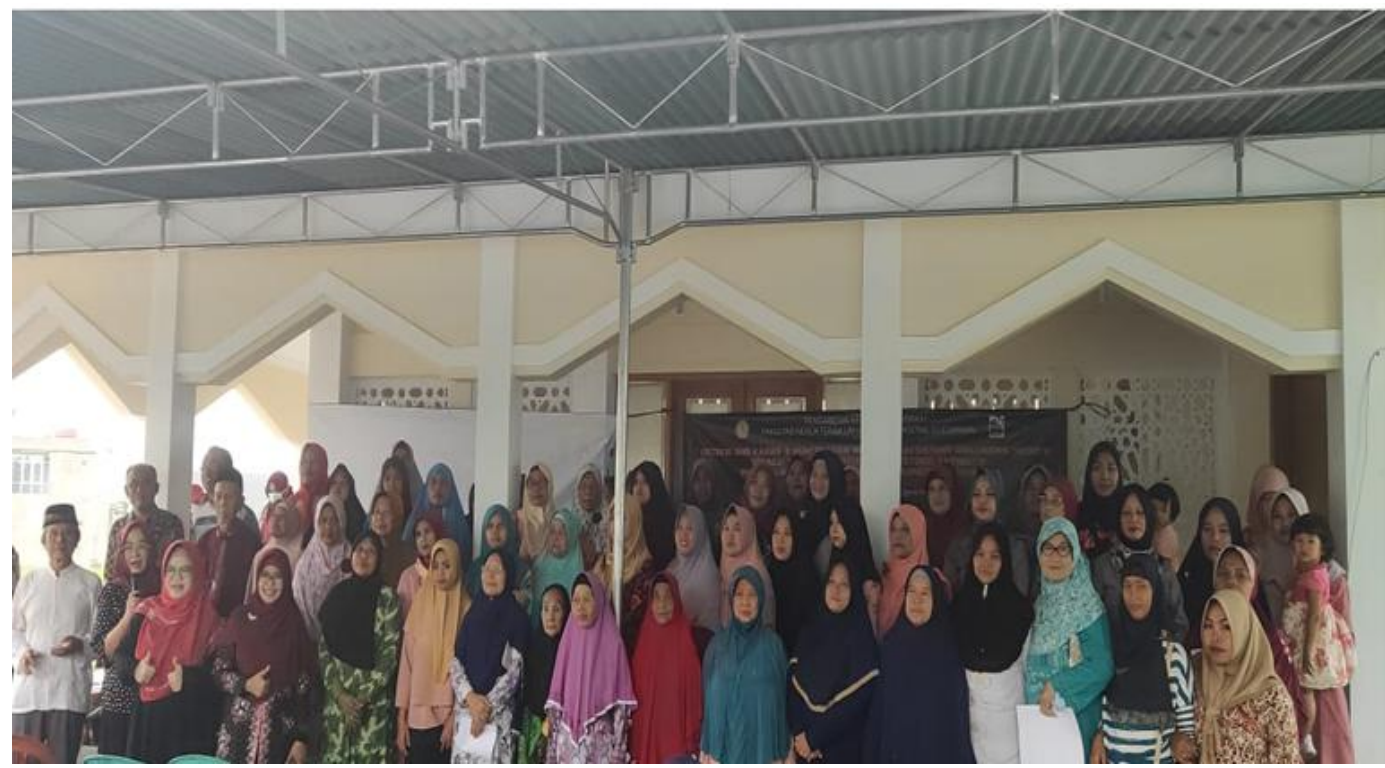

Gambar 2. Foto bersama seluruh peserta Pengabdian

Fungsi logistik dan domestik anggota posdaya sebagai ibu rumah tangga sangat sesuai untuk mengemban tugas sebagai kader masyarakat dalam meningkatkan kesadaran penggunaan antibiotik secara bijak. Penggunaan antibiotik secara bijak dapat di mulai dari setiap individu dan keluarga sebagai unit masyarakat terkecil. Secara bertahap, diharapkan kader posdaya yang telah memiliki pemahaman dan kesadaran tentang penggunaan antibiotik bijak dapat memberi edukasi pada anggota posyandu/posdaya yang lain untuk berkomitmen menggunakan antibiotik bijak dan mencegah penyebaran bakteri resisten dalam komunitas di wilayahnya. Kegiatan yang dijalankan secara konsisten dan berkesinambungan pada akhirnya dapat berperan dalam mengendalikan resistensi antibiotik pada wilayah yang lebih luas sampai ke tingkat nasional. 


\section{KESIMPULAN}

Hasil Skrining menunjukkan bahwa bakteri S.aureus yang ditemukan dalam masyarakat masih bersifat sensitif terhadap antibiotik, namun penggunaan antibiotik yang tidak bijak masih ditemukan pada anggota posdaya Sunan Kalijaga, Berkoh, Purwokerto.

\section{UCAPAN TERIMA KASIH}

Ucapan terima kasih disampaikan kepada LPPM Unsoed yang telah memberikan hibah Pengabdian Masyarakat Berbasis Riset tahun 2019. dr.Nia Krisniawati SpMK atas konsultasi Laboratorium Klinis dan Seluruh Staf Departemen Mikrobiologi FK Unsoed atas kerjasamanya dalam meyelesaikan pengabdian masyarakat.

\section{DAFTAR PUSTAKA}

Anjarwati, D. U., Setyono, J., Rujito, L. 2011. Perawat kesehatan sebagai karier methicillin resistant staphylococcus aureus (MRSA) di rumah sakit pemerintah dan rumah sakit swasta Kabupaten Banyumas. Mandala of Health, 5 (1).

Clinical laboratory Standard Institute. 2019. Performance Standards for Antimicrobial Susceptibility Testing, M100, $29^{\text {th }}$ Ed. Wayne, USA.

Hadi, U., Duerink, D. O., Lestari, E. S., Nagelkerke, N. J., Werter, S., Keuter, M. 2008. Survey of antibiotic use of individuals visiting public healthcare facilities in .Indonesia International Journal of Infectious Diseases, 12 : 622-629. DOI.10.1016/j.ijid.2008.01.002.

O'Neill, J. 2014. Antimicrobial Resistance: Tackling a crisis for the health and wealth of nations. The Review on Antimicrobial Resistance. Wellcome Trust and the UK Government.

Permenkes. 2015. Peraturan Menteri Kesehatan Republik Indonesia Nomor 8 Tahun 2015 Tentang Program Pengendalian Resistensi Antimikroba Di Rumah Sakit.

Santosaningsih, D., Zuhriyah, L., Nurani M. P. 2011 . Staphylococcus aureus pada Komunitas Lebih Resisten terhadap Ampisilin dibandingkan Isolat Rumah Sakit. Jurnal Kedokteran Brawijaya, 26 (4) : 204-207.

Ulla, I. M., Afifah, Anjarwati, D. U. 2018. Hubungan Riwayat Penggunaan Antibiotik Dengan Karier Eschericia coli Penghasil Extended Spectrum Beta Lactamase (ESBL) Pada Mahasiswa FK Unsoed Angkatan 2014 S1. Thesis. Universitas Jenderal Sudirman, Purwokerto.

WHO. 2014. Antimicrobial Resistance Global Report on Surveilance www.who.int. 